\title{
FEEDING HABITUATION TO RED CLOVER BY CLOVER ROOT WEEVIL ADULTS
}

\author{
P.J. GERARD and J.R. CRUSH \\ AgResearch, Ruakura Research Centre, Private Bag 3123, Hamilton, \\ New Zealand \\ Corresponding author: pip.gerard@agresearch.co.nz
}

\begin{abstract}
Red clover (Trifolium pratense) has been observed to persist longer than white clover (T. repens) during field screening of legumes for tolerance of clover root weevil (Sitona lepidus). It has been suggested that this is linked to adult feeding preferences. A laboratory trial was undertaken to confirm the feeding preference for white clover over red, and to determine whether adults became habituated to red clover over time. Groups of clover root weevil adults were caged on either white clover cv. Grasslands Huia or 3 lines of Grasslands Pawera red clover. At weeks 2, 4, 6 and 8 subsamples of adults were removed from the cages and were subjected to a $24 \mathrm{~h}$ choice test. It was found that, although adults showed a strong preference for white clover, those that had been continuously fed red clover were more likely to feed on red clover in the choice test than those that had previously been fed white clover.
\end{abstract}

Keywords: Sitona lepidus, white clover, red clover, feeding, habituation.

\section{INTRODUCTION}

Current field evaluations of a wide range of clover germplasm in pastures infested by clover root weevil (CRW) (Sitona lepidus Gyllenhal (Coleoptera: Curculionidae)) have shown that red clover (Trifolium pratense) is damaged less than white clover (T. repens) (Eerens et al. 2001). Results suggest that this is linked to adult feeding preferences, but it is not known whether red clover will be readily eaten by the weevil if no white clover is present.

Mixed results have been reported in previous laboratory studies. Murray \& Clements (1994) found no significant difference in CRW adult feeding levels between white (cv. Olwen) and red clover (cv. Marcom) in $48 \mathrm{~h}$ choice and no-choice experiments. However, later Murray (1996a) found adults fed less on red than white in both choice and nochoice experiments over a $60 \mathrm{~h}$ period. The difference between these two studies could be related to attributes of the unspecified cultivars used in the second study. CRW has shown clear preferences between white clover cultivars, possibly negatively related to cyanogenesis potential (Murray \& Clements 1993; Murray 1996b).

An experiment was undertaken to determine the responses of CRW adults to three 'Grasslands Pawera' red clover populations and white clover, over time. This paper reports selected results from this experiment, namely the comparison of CRW feeding preferences between red and white clover after habituation.

\section{Habituation of CRW}

\section{METHODS}

CRW adults were collected from a Waikato ryegrass (Lolium perenne)/white clover pasture in November 2002 using a suction apparatus (modified Homelite HB180V blower/ vac.) and sorted into batches of 100. Each batch was placed in the mesh-based top of a two-tier cage (Goldson et al. 1992), along with a supply of leaves from one of the three Pawera-type red clovers or the white clover (cv. Grasslands Huia). The clovers were vigorous plants grown in fertile potting mix in a temperature-controlled glasshouse. 
The leaf petioles were inserted into a vial of water to prevent wilting, and the clover was changed twice weekly to ensure fresh foliage was always available. There were four replicates for each clover. The cages were held at $15^{\circ} \mathrm{C}, 16: 8 \mathrm{~h}$ light:dark for eight weeks.

\section{Feeding preferences}

Adult feeding preferences were assessed after 0,2, 4, 6 and 8 weeks habituation. One petiole of a mature leaf from each of the three red clovers and several white clover leaves were inserted into a $50 \times 10 \mathrm{~mm}$ glass tube filled with water and firmly plugged with absorbent cotton wool. Several white clover leaves were required to give leaf area that was equivalent to the larger-leafed red clovers. The vial and clover were placed in a $150 \mathrm{ml}$ plastic pot, along with five adult CRW, and the pot covered with mesh. There were 10 replicates containing weevils and four control replicates with no weevils. The latter were used to correct leaf area data for changes associated with moisture content during the assay. The pots were held at $15^{\circ} \mathrm{C}, 16: 8 \mathrm{~h}$ light:dark for $24 \mathrm{~h}$ then the clovers were assessed for feeding damage by counting feeding notches and determining the loss in leaf area using WinRhizo ${ }^{\mathrm{TM}}$ image analysis software.

\section{Statistical analysis}

Feeding damage data were analysed using ANOVA, with log transformation of leaf area data. The three red clovers gave essentially similar results, so data from them was pooled. Means were compared using least significant differences (LSD) obtained from t-tests.

\section{RESULTS}

Throughout the duration of the eight-week experiment, CRW preferred feeding on white clover to red clover, with significantly higher notching levels (Fig. 1, P<0.001) and leaf area losses (Fig. 2, $\mathrm{P}<0.01$ ). Overall, weevils that had previously been fed red clover (red diet CRW) produced twice the level of notching/leaf on red clover in the choice tests than weevils that had been fed white (white diet CRW) $(10.9$ versus 5.9, $\mathrm{P}<0.001)$ with significant differences at weeks 2, 4 and 6 (Fig. 1). In addition, red diet CRW produced fewer notches on white clover than white diet CRW (40.9 versus 48.2, $\mathrm{P}<0.01$ ), although in the individual choice tests, this was only significant at week 6 (Fig. 1).

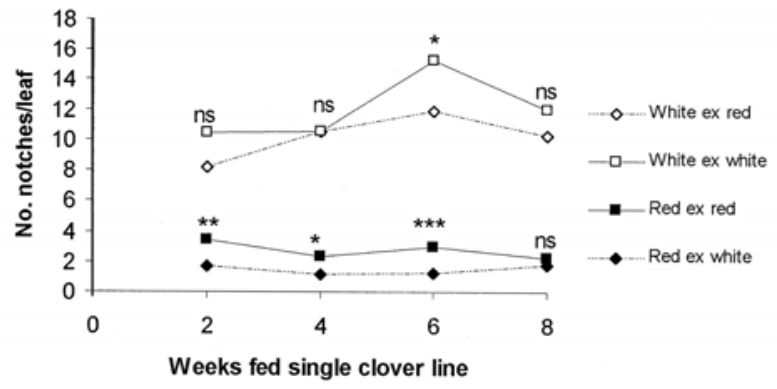

\section{FIGURE 1: Effect of duration of prior clover diet on mean number of feeding notches on red and white clover leaves after $24 \mathrm{~h}$ exposure to five clover root weevil adults in a choice test. Asterisks denote significant differences between pairs of red or white clover means; ns indicates the difference is not significant.}

The overall leaf area results were similar. Red diet CRW ate over twice as much red clover as white diet CRW ( 8.3 versus $3.0 \mathrm{~mm}^{2}, \mathrm{P}<0.05$ ), with significant differences at weeks 2, 6 and 8 (Fig. 2). No difference was found between red diet and white diet CRW in the leaf area of white clover consumed. 


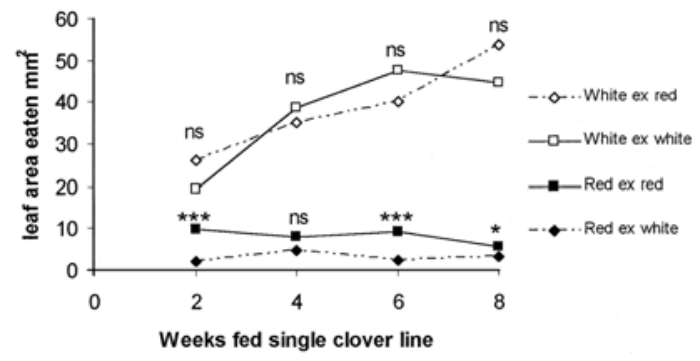

FIGURE 2: Effect of duration of prior clover diet on mean leaf area loss from red and white clover leaves after $24 \mathrm{~h}$ exposure to five clover root weevil adults in a choice test. Asterisks denote significant differences between pairs of red or white clover means; ns indicates the difference is not significant.

The average size of leaf notches was estimated for each replicate by dividing leaf area consumed by the corresponding number of notches. Overall, mean notch size on red clover was smaller than that on white clover $(\mathrm{P}<0.05)$. The differences between the four combinations were greatest at Week 8 (Fig. 3), with red diet CRW producing larger notches than white diet CRW on both red $(\mathrm{P}<0.05)$ and white clover $(\mathrm{P}<0.05)$.

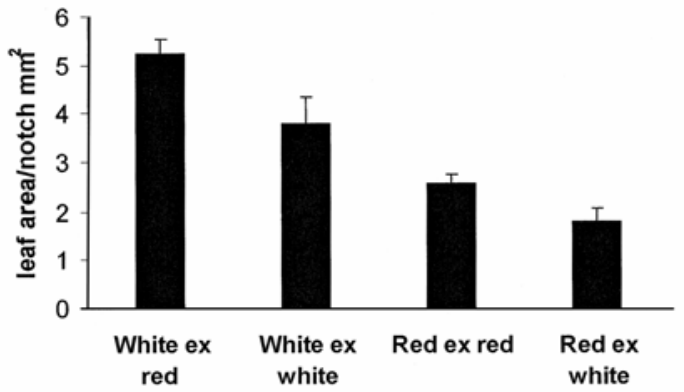

FIGURE 3: Effect of prior clover diet on mean leaf area/notch on red and white clover leaves after $24 \mathrm{~h}$ exposure to five clover root weevil adults in a choice test at eight weeks.

\section{DISCUSSION}

While Trifolium species are the preferred host plants for CRW, it is known that the weevil exhibits considerable preferences between species, and some preferences between cultivars within these species (Murray \& Clements 1994; Murray 1996a). Mowat \& Shakeel (1989) related Sitona spp. damage to levels of cyanogenic compounds in white clover varieties. However, New Zealand white clovers, such as Grasslands Huia, are much more cyanogenic (Crush \& Caradus 1995) than the European cultivars that showed variation in CRW damage, yet are readily eaten by CRW. In addition, red clovers are acyanogenic. Therefore, observed adult feeding preferences between red and white clovers are not related to cyanogenesis, and other antifeedants, such as phytoalexins (Murray \& Clements 1994), might be responsible.

Irrespective of the nature of the antifeedant, physiological mechanisms in some insects, such as habituation to deterrents, can lead to changes in food preference responses over time (Bernays \& Weiss 1996). For instance, Pieris rapae larvae can become habituated 
to the feeding deterrents in nasturtium Tropaeolum majus if exposed as neonates (Hunag \& Renwick 1995).

The results of this choice experiment clearly show that white clover cv. Huia is preferred as a food over red clover populations derived from the cultivar Pawera, and that this preference was maintained throughout the 8 week duration of the experiment. However, it also shows that prior exposure to red clover led to greater acceptability of red clover as a host plant. These results suggest that if antifeedants are the only mechanism that protects red clover from adult CRW attack, then red clover may be susceptible in the absence of white clover. The potential severity of the damage will depend on the fecundity of CRW feeding on red clover, and the susceptibility of red clover to root damage caused by CRW larvae. CRW larval damage to roots seems to be the major cause of CRW-induced mortality of white clover in infested pastures.

The notch size data indicate that CRW adults, especially those that have been feeding on white clover, take smaller notches from leaves of red clover than from white. This did not appear to be related to leaf thickness, as there was no apparent difference in water content nor leaf weight per unit leaf area data between white and red clover samples (P.J. Gerard, unpubl. data). What has more importance is that at eight weeks, red diet CRW were producing larger notches than white diet CRW on white clover. This may have important implications for establishment and persistence of white clover in mixed pastures with red clover.

Further studies on possible resistance mechanisms in red clover and their effects on CRW biology and physiology are currently being completed.

\section{ACKNOWLEDGEMENTS}

The authors wish to acknowledge the dedicated technical input of Deborah Hackell, Miriana Knox and Li Ouyang, and Catherine Cameron for statistical analyses. The research was co-funded by the Foundation for Research, Science and Technology, Meat and Wool NZ, Dairy Insight and Deer Industry NZ.

\section{REFERENCES}

Bernays, E.A.; Weiss, M.R. 1996: Induced food preferences in caterpillars: the need to identify mechanisms. Entomol. Exp. Appl. 78: 1-8.

Crush, J.R.; Caradus, J.R. 1995: Cyanogenesis potential and iodine concentration in white clover (Trifolium repens L.). N.Z. J. Agric. Res. 38: 309-316.

Eerens, J.P.J.; Cooper, B.M.; Willoughby, B.E.; Woodfield, D.R. 2001: Searching for clover root weevil (Sitona lepidus) resistance/tolerance - A progress report. Proc. N.Z. Grassland Assoc. 63: 177-181.

Goldson, S. L.; McNeill, M.R.; Phillips, C.B.; Proffitt, J.R. 1992: Host specificity testing and suitability of the parasitoid Microctonus hyperodae (Hym.: Braconidae, Euphorinae) as a biological control agent of Listronotus bonariensis (Col.: Curculionidae) in New Zealand. Entomophaga 37: 483-498.

Hunag, X.P.; Renwick, J.A.A. 1995: Chemical and experimental basis for rejection of Tropaeolum majus by Pieris rapae larvae. J. Chem. Ecol. 21: 1601-1617.

Mowatt, D.J.; Shakeel, M.A. 1989: The effect of some invertebrate species on the persistence of white clover in ryegrass swards. Grass Forage Sci. 44: 117-124.

Murray, P.J.; Clements, R.O. 1993: Feeding preferences among eleven cultivars of white clover (Trifolium repens) by adults of two species of Sitona weevil (Coleoptera: Curculionidae). Tests Agrochem. Cult. 14 (Ann. Appl. Biol. 122, Supplement): 134-135.

Murray, P.J.; Clements, R.O. 1994: Investigations of the host feeding preferences of Sitona weevils found commonly on white clover (Trifolium repens) in the UK. Entomol. Exp. Appl. 71: 73-79.

Murray, P.J. 1996a. Influence of food source on feeding, longevity and fecundity of Sitona flavenscens (Coleoptera: Curculionidae), a major pest of white clover in the UK. In: Frame, J. ed. Recent research and development on white clover in Europe. REU Technical Series, FAO, Rome. Pp. 118-121.

Murray, P.J. 1996b: Evaluation of a range of varieties of white clover for resistance to feeding by weevils of the genus Sitona. Plant Var. Seeds 9: 9-14. 